- використання освітніх технологій, яке реалізується в системі комплексних лабораторно-практичних занять, що об'єднують теорію, методику і практику педагогічної освіти;

- усвідомлення тими, хто навчається, особистісного і професійного сенсу саморозвитку, самовиховання, самонавчання, самоорганізації;

- відповідність характеру освітнього процесу індивідуальнотипологічним характеристикам студентів (здібностям, усвідомленої орієнтації на професію педагога, здібності до самостійного засвоєння змісту предметних знань, мотиваційно-вольові якості).

Висновки. Отже, кожна 3 визначених умов характеризується різними якісними і кількісними рівнями. Сукупність умов забезпечує ефективність технологій професійно-особистісної підготовки майбутнього педагога на певному рівні розвитку соціально-освітньої сфери суспільства. У якості методологічної основи визначення дидактичних умов визначено системний, діяльнісний, диференційований, аксіологічний, суб'єктно-діяльнісний, предметно-пізнавальний підходи. При цьому останній співвідноситься 3 методикою викладання конкретного навчального предмета. Використання перерахованих підходів у проектуванні освітніх технологій, їх реалізація надає можливість удосконалення процесу управління самостійною навчальною діяльністю студенів заочної форми навчання.

\title{
Література
}

1. Сластёнин В. А. Профессионально-педагогическая подготовка современного учителя / В. Сластёнин, А. Мищенко // Сов. педагогика.- 1991. - № 10. - С. 79-84.

2. Сластёнин В. А. Субъектно-деятельностный подход в непрерывном педагогическом образовании / В. А. Сластёнин // Непрерывное педагогическое образование. -1998.- № 1.- С. 7-11.

3. Талызина И. Ф. Управление процессом усвоения знаний: психологические основы / И. Ф. Талызина.- М. : МГУ, 1984. - 344 с.

Стаття надійшла до редакції 30.04.2012 p.

УДК 378. 22.016:5:[373.5]

В. В. Оніпко,

кандидат сільскогосп. наук, доцент,

Полтавський національний педагогічний університет

імені В. Г. Короленка

\section{МОДЕЛЮВАННЯ СИСТЕМИ ПРОФЕСІЙНО-ПЕДАГОГІЧНОӤ ПІДГОТОВКИ МАЙБУТНІХ УЧИТЕЛІВ ПРИРОДНИЧИХ ДИСЦИПЛІН ДО ПРОФЕСІЙНОЇ ДІЯЛЬНОСТІ У ПРОФІЛЬНІЙ ШКОЛІ}

Оніпко В. В. Моделювання системи професійно-педагогічної підготовки майбутніх учителів природничих дисииплін до професійної діяльності у профільній школі.

У статті розглянуто наукові основи моделювання процесу підготовки майбутнього вчителя, теоретично обтрунтовано використання сучасної функиіональної багатошарової моделі у вищій педагогічній освіті, визначено спещифіку побудови і реалізацію сендвіч-моделі професійнопедагогічної підготовки майбутніх учителів природничих дисциплін до професійної діяльності у профільній середній школі.

Ключові слова: вища педагогічна освіта, майбутній учитель природничих дисииплін, моделювання прочесу підготовки, сендвіч-модель, профільна середня школа. 
Онипко В. В. Моделирование системь профессионально-педагогической подготовки будущих учителей естественных дисциплин к профессиональной деятельности в профильной школе.

В статье рассматриваются научные основы моделирования процесса подготовки будущего учителя, теоретически обосновывается использование современной многослойной модели в высшем педагогическом образовании, определяется специфика построения сэндвичмодели профессионально-педагогической подготовки будущих учителей естественных дисииплин к профессиональной деятельности в профильной средней школе.

Ключевые слова: высшее педагогическое образование, будущий учитель естественных дисииплин, моделирование прочесса подготовки, сэндвич-модель, профильная средняя школа.

Onipko V. Modeling professional and pedagogical training of teachers of natural sciences to the profession in specialized schools.

The article discusses the scientific basis of modeling the process of preparing future teachers, it is theoretically justified by the use of modern multi-layer model of teacher education in the highest, specificity is determined by the construction of the sandwich model of vocational and educational training of future teachers of natural sciences to the professional profile in high school.

Key words: higher education teacher education, the future teacher of natural sciences, simulation training, the sandwich model, profile high school.

Постановка проблеми. У сучасних умовах результатом освіти має стати не тільки самовизначення і самореалізація учнів, але формування їх особистості, що відповідає суспільним потребам, перспективам розвитку суспільства, здатної адаптуватися до змінених умов й активно працювати. Випускник школи має вміти самостійно здійснювати вибір життєвого шляху, конструювати особисту траекторію творчого професійного зростання. Це $\epsilon$ свідченням необхідності розгляду освітнього процесу 3 позиції його взаємозв'язку із соціумом, а системи освіти як невід'ємного складника соціокультурного простору. Забезпечення функціонування і розвитку таких систем у контексті особистісно і соціально орієнтованої парадигми освіти, що передбачає реалізацію і самореалізацію закладеного в людині особистісного потенціалу відповідно до соціально зумовлених освітніх запитів, що неможливе без високого рівня науково-методичного забезпечення педагогічних працівників. Тому питання підготовки майбутніх учителів до професійної діяльності у профільній середній школі залишається пріоритетним [2]. У цьому зв’язку особливого значення набувають функціональні моделі професійно-педагогічної підготовки, що дозволяють точно фіксувати структурні зміни будь-якої системи й відображати їх в узагальненій формі. Такі моделі, що виконують різноманітні функції (описову, управлінську і прогностичну), необхідні для аналізу ефективності функціонування системи професійно-педагогічної підготовки майбутніх учителів, визначення іii оптимальних умов, прогнозування і проектування іiі розвитку.

Аналіз останніх досліджень і публікацій. Вивчення стану наукового розроблення означеної педагогічної проблеми довело, що вітчизняними та зарубіжними науковцями глибоко досліджено різні аспекти технології процесу підготовки фахівців. Науковому розв'язанню проблеми вдосконалення професійної підготовки вчителя сприяли дослідження етапів розвитку вищої педагогічної освіти в Україні та за рубежем (В. Андрущенко, Н. Абашкіна, О. Абдулліна, І. Зязюн, М. Свтух， Н. Кузьміна, В. Кремень, Д. Ніколенко, 
Н. Ничкало); тенденцій розвитку системи університетської освіти (А. Алексюк, В. Сагарда, О. Глузман, Л. Коваль, О. Мєщанінов); організації навчального процесу у вищих педагогічних навчальних закладах (А. Вербицький, С. Гончаренко, М. Євтух， В. Козаков, М. Шкіль); концепції педагогічної майстерності (С. Барбіна, І. Зязюн, В. Сластьонін) та теорії педагогічної взаємодії (І. Бех, О. Бодальов, А. Бойко, А. Добрович, В. Казанська, В. КанКалик, О. Лсонтьєв). Проблема професійної освіти з урахуванням ефективності використання моделювання дидактично-технологічної підготовки студентів привертала увагу таких науковців: І. Блауберг, Н. Кузьміна, К. Платонов, В. Садовський, Е. Юдін, В. Шадриков та ін. Проблема моделювання у вищих педагогічних навчальних закладах в умовах профільного навчання є соціально зумовленою і вкрай актуальною. Водночас, контекстний аналіз довів, що поглибленого і системного вивчення потребують також питання підготовки висококваліфікованих педагогічних працівників для роботи у профільній школі, відсутня педагогічна модель відповідного оновлення структури, змісту, форм, методів та інноваційних технологій навчально-виховного процесу майбутніх учителів природничих дисциплін профільної середньої освіти.

Метою написання статті $\epsilon$ розроблення моделі, яка відображає взаємозв'язки та взаємозалежності між проектованими якостями i властивостями особистості майбутнього вчителя природничих дисциплін; 3'ясувати специфіку побудови функціональної багатошарової моделі у вищій педагогічній освіті, які мають цільовий, мотиваційний, змістовий, діяльнісно-операційний, оцінно-результативний та рефлексивний складники.

Виклад основного матеріалу. Зміни, що відбуваються в сучасному суспільстві, призводять до реформування та модернізації навчальновиховного процесу і диктують нове розуміння цілей, форм і методів освіти при підготовці вчителя до профільного навчання учнів. Вони мають бути орієнтованими не стільки на засвоєння знань, скільки на розвиток пізнавальних і творчих здібностей майбутнього вчителя, формування ціннісного мислення і критичного ставлення до навколишньої дійсності й до самого себе. Акцент в сучасній освіті переноситься із «засвоєння знань» на формування «компетентності», відбувається його адаптація до особистісно зорієнтованого (гуманістичного) підходу, протилежного психологоорієнтованій, безособистісній педагогіці. Ефективність дидактичного процесу значною мірою визначається адекватним вибором і професійною реалізацією конкретних педагогічних технологій у вищій школі.

Розглядаючи сучасні науково-педагогічні підходи, в основу моделювання системи професійно-педагогічної підготовки майбутніх учителів природничих дисциплін до професійної діяльності у профільній школі нами покладено математичне поняття «багатошарової моделі», тобто моделі, що складається 3 цілої низки багатофункціональних площин [4, с. 111]. Такі багатошарові моделі у подальшому будемо називати сендвіч-моделями (СМ) [3]. Дамо деякі пояснення до їх застосування. Шари сендвіч-моделі становлять паралельні площини, які відповідають функціональним складовим 
досліджуваного явища, складаються 3 елементів та зв'язків між ними. За таких умов ураховуються як зв'язки, що наявні у межах кожної площини, так і ті, що наявні між самостійними одиницями (площинами, шарами) сендвіч-моделі. Кожна площина СМ розглядається як самостійна модель ряду складників. Окрім того, площини СМ можуть включати структури різних організаційних та функціональних складових. Зв'язки між різними площинами СМ відображають та формалізують процеси взаємодії окремих площин. Елементами СМ є вузли, вектор-мітки, ребра. Застосування саме сендвіч-моделі зумовлене необхідністю відображати в досліджуваних моделях наявність накладання та взаємодії у системі підготовки окремих суб'єктів структурних одиниць, підрозділів зі своїми розвиненими організаційними структурами. Наведемо коротку характеристику елементів СМ та їх змістову інтерпретацію у загальному вигляді. Вузол - елемент підсистеми, що має бути явно заданим у моделі. Вектор-мітка вузла - набір параметрів, що характеризують цей вузол. Функціональна площина сендвіч-моделі множина пов'язаних між собою вузлів (об'єктів), упорядкована згідно 3 певним логічним правилом. Ребра моделі - зв'язки, що наявні між вузлами. Ребра можуть з’єднувати вузли як у межах однієї функціональної площини (зв'язок горизонтального типу), так i вузли, що належать різним функціональним площинам (зв’язок горизонтального типу) [4; с. 112]. Відповідно до мети дослідження розглядають більш прості частини сендвічмоделі, які отримують шляхом вертикальних перерізів загальної СМ. Викладене вище дає можливість представити сендвіч-модель системи професійно-педагогічної підготовки майбутніх учителів природничих дисциплін до роботи у профільній школі на основі виокремлення чотирьох функціональних площин (підсистем): зовнішньої або соціальної; загальної або реалізації професійно педагогічної підготовки; внутрішньої або структурно-змістової; локальної або прикладної (рис. 1).

Зовнішня (соціальна) площина відображає характер соціального середовища, соціальних умов, які грунтуються на багатовимірності й багатоваріантності історичного розвитку, його альтернативності, 3 одного боку, і безповоротності еволюційного руху - 3 іншого. Саме ця площина визначає наповнення горизонтальної і локальної складових цілісної системи. Загальна (горизонтальна) площина відображає цілісність реалізації професійно-педагогічної підготовки в межах одного навчального закладу на основі спеціально підібраної, чітко окресленої, певним чином згрупованої системи елементів, які пов'язані між собою механізмом обміну сигналами (вхідними і вихідними). Внутрішня (структурно-змістова) площина - надає цілісне структурно-теоретичне уявлення про підсистеми горизонтальної оболонки (вивчення предметів інтегрованого циклу), науково-дослідна робота, педагогічна i виробнича практики, самоосвіта тощо. Локальна (прикладна) площина $є$ найбільш простою системою стосовно попередніх оболонок, має практичний характер, відображає конкретну авторську систему підготовки. 


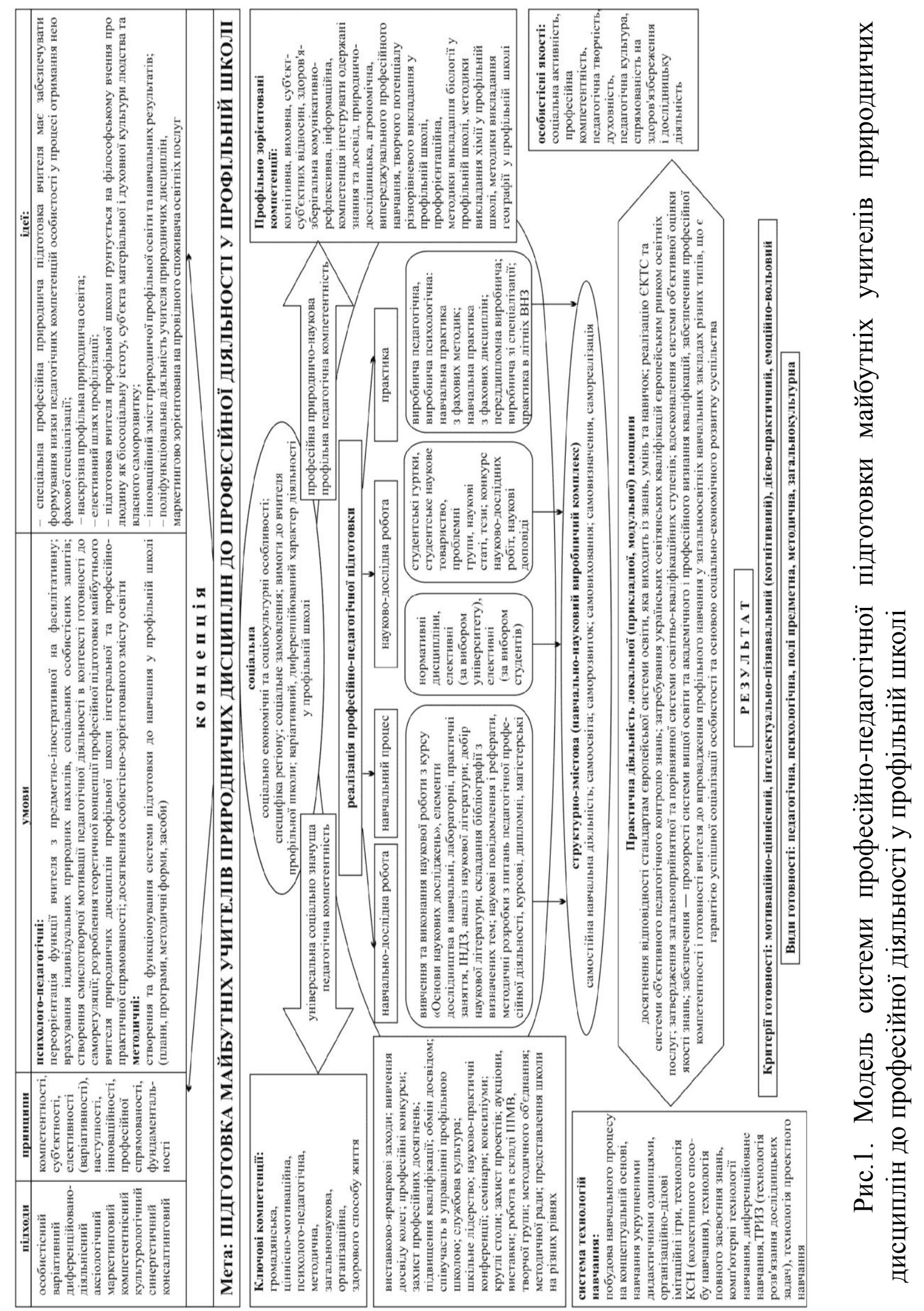


Кожна 3 названих функціональних площин СМ має особливості цільового, змістового, прикладного характеру, окреслення яких іє завданням нашого подальшого пошуку.

Зовнішню площину педагогічної системи професійно-педагогічної підготовки студентів університетів розглядатимемо як частину метасистеми (соціальна оболонка), тобто середовища, в якому вона функціонує. Такий підхід дозволить дати чітку сутнісну характеристику інших складових сендвіч-моделі, оскільки структурні елементи педагогічних систем найбільш чутливі до змін, які відбуваються у всіх сферах суспільного життя і ними визначаються. Лише таке загальне уявлення про досліджуваний системний об'єкт визначає перспективи детального вивчення певних його компонентів. Співвідношення цілого й одиничного надає можливість визначити їх необхідність і достатність, зумовлену відношенням кожної частини до цілого, а водночас - і один до одного.

Пропонована профільно зорієнтована організаційно-функціональна сендвіч-модель підготовки майбутнього вчителя природничих дисциплін до професійної діяльності на основі теоретично обгрунтованої концепції як компетентнісно-інтегративної організаційно-методичної цілісності процесу підготовки фахівця, даних включеного спостереження й експериментального пошуку враховує, що майбутнього вчителя природничих дисциплін профільної школи має характеризувати людинознавча компетентність, заснована на комплексі цінностей, фахових знань і досвіду профільної педагогічної діяльності, орієнтованих на всебічний розвиток особистості в соціально-педагогічному середовищі тривалий період життя, особливого типу навички моделювання та організації освітнього середовища профільної школи, соціально-економічні та соціокультурні особливості специфіку регіону; соціальне замовлення; вимоги до вчителя профільної школи; варіативний, диференційований характер діяльності у профільній школі. Упровадження вимог до системи професійно-педагогічної підготовки студентів університетів, поставлених на соціальному рівні (зовнішня площина), вимагає внесення змін у структурні елементи площин нижніх рівнів, серед яких особливе місце посідає загальний (горизонтальний) складник - реалізація завдань професійно-педагогічної підготовки майбутніх вчителів до професійної діяльності у профільній школі. Специфікою змістового наповнення зазначеної складової є наявність елективних курсів. Студенти педагогічних вишів включені у такі види діяльності: навчальний процес (з опорою на профіль, включаючи відповідний обсяг предметів нормативних та елективних дисциплін), навчально-дослідна робота майбутнього вчителя (вивчення та виконання наукового дослідження з курсу «Основи наукового дослідження», елементи дослідництва в навчальних, лабораторних, практичних заняттях, ІНД3, аналіз наукової літератури, опрацювання літературних джерел; добір наукової літератури, складання бібліографії 3 визначених тем; наукові повідомлення і реферати, методичні розробки 3 питань педагогічної професійної діяльності, наукові звіти досліджень під час 
практики, курсові, дипломні, магістерські), науково-дослідна робота (студентські гуртки, студентське наукове товариство, проблемні групи, наукові статі, тези; конкурс науково-дослідних робіт, наукові доповіді), навчальні та педагогічна практика.

У процесі реалізації завдання дослідження - розроблення профільно зорієнтованої організаційно-функціональної моделі поетапної професійної підготовки, особистісного самоздійснення майбутнього вчителя природничих дисциплін до професійної діяльності у профільній школі методами теоретичного, генетичного, функціонально-структурного моделювання. Виокремлено комплекс його цінностей, фахових знань і досвіду та визначено сукупність основних компетенцій для конструювання наскрізної професійнопедагогічної програми та професіограми, що має інтегрований характер. Комплекс фахових знань охоплює знання 3 філософії, екологічної етики, історії, української культури, культурології, фізики, економічної теорії, основ екології, геології з основами геохімії, охорона природи, неорганічної хімії, нових інформаційних технологій і ТЗН, органічної хімії, біосферології, основ медичних знань, картографії 3 основами топографії, загального землезнавства, метеорології та кліматології, гідрології, біогеографії, географії грунтів з основами грунтознавства, ландшафтознавства, методики географічних досліджень, основ суспільної географії, дендрології, палеозоології, психології, педагогіки, вікової фізіології і валеології, педагогічної технології, методики педагогічного експерименту, методики виховної та соціальнопедагогічної діяльності вчителя, географії населення і розселення, безпеки життєдіяльності та основ охорони праці, аналітичної, органічної, фізичної, колоїдної хімії, ботаніки (морфологія та анатомії, систематики рослин), зоології (безхребетних, хребетних тварин), анатомії людини, основ сільського господарства, грунтознавства, загальної цитології і гістології, генетики з основами, селекції, основ, туризму, основ технології промислового й сільськогосподарського виробництва, основ педмайстерності, методики використання комп'ютерних програм у шкільному курсі хімії, природознавства, лікарських рослин, основ наукових досліджень в біології, екології рослин і тварин, флори і рослинності, фізичного виховання, фізикохімічних методів дослідження, фізіології людини та тварин та ін. Компонентами моделі та відповідної ій наскрізної професійно-педагогічної програми визначено універсальну соціально значущу педагогічну компетентність майбутнього вчителя природничих дисциплін: проектувально-конструктивні, організаційно-мобілізуючі, соціально-прогностичні, діагностувальні, організаційні, комунікативно-рефлексивні, культурологічні (громадянська, ціннісномотиваційна, психолого-педагогічна, методична, загальнонаукова, організаційна, здорового способу життя) компетенції та професійну природничонаукову профільно-педагогічну компетентність (когнітивна, виховна, суб'єктсуб’єктних відносин, здоров'язберігальна, комунікативно-рефлексивна, інформаційна, компетенція інтегрувати одержанні знання та досвід, природничо-дослідницька, агрономічна, випереджувального професійного 
навчання, творчого потенціалу, різнорівневого викладання у профільній школі, профорієнтаційна, методики викладання біології у профільній школі, методики викладання хімії у профільній школі, методики викладання географії у профільній школі) компетенції.

Кожен попередній (більш простий) компонент моделі є підгрунтям для формування наступного, більш складного, ступінь сформованості більш складних компонентів визначає рівень оволодіння більш простими. Означена система взаємозв'язків між компонентами обумовлює цілісний характер горизонтальної складової та забезпечує доцільний перехід на наступний рівень моделі. Структурно-змістова (навчально-науковий виробничий комплекс) складова моделі зумовлюється відмінностями у підготовці фахівців до роботи у профільній школі. Особливого значення набувають: самостійна навчальна діяльність; самоосвіта; саморозвиток; самовиховання; самовизначення, самореалізація. Педагогічна складова для природничих спеціальностей $є$ їх атрибутивним елементом і реалізується у процесі профільно зорієнтованих заходів (виставково-ярмаркові заходи; вивчення досвіду колег; професійні конкурси; захист професійних досягнень; підвищення кваліфікації; обмін досвідом; співучасть в управлінні профільною школою; службова культура; шкільне лідерство; науково-практичні конференції; семінари; консиліуми; круглі столи; захист проектів; аукціони, виставки; робота в складі ШМВ, творчої групи; методичного об'єднання; методичної ради; представлення школи на різних рівнях). Як найбільш загальний компонент цілісної системи підготовки розглядаємо іiі відповідність стандартам ЄКТС та вимоги об'єктивного педагогічного контролю знань; затребування українських освітянських кваліфікацій європейським ринком освітніх послуг; затвердження загальноприйнятної та порівнюваної системи освітньо-кваліфікаційних ступенів; удосконалення об’єктивної оцінки якості знань; забезпечення прозорості системи вищої освіти та академічного і професійного визнання кваліфікацій, забезпечення професійної компетентності і готовності вчителя до впровадження профільного навчання у загальноосвітніх навчальних закладах різних типів, що є гарантією успішної соціалізації особистості та основою соціально-економічного розвитку суспільства. Вона є принципово новим явищем: 3 одного боку, передбачає реалізацію у контексті надання випускникам конкурентноздатності на ринку освітніх послуг, 3 іншого, загальної підготовки, що визначає наскрізну гуманізацію природничої (фундаментальної) підготовки. Потреба в фахівцях, готових до життя у постійно змінюваному соціумі, налаштованих і здатних творити нове у своїй діяльності, стимулювати, каталізувати (прискорювати) інноваційні освітні процеси, вихід яких на новий рівень забезпечує стабільність і розвиток соціуму орієнтує професійну підготовку на особистісну орієнтацію, спрямовану на те, щоб майбутній фахівець став повноцінним, самодостатнім, творчим суб'єктом діяльності, пізнання, спілкування, вільною і самодіяльною особистістю, готовою до професійної діяльності у профільній школі. У межах гуманістичної освітньої парадигми принципово іншими є особистісні якості 
майбутнього вчителя природничих дисциплін (соціальна активність, професійна компетентність, педагогічна творчість, духовність, педагогічна культура, спрямованість на здоров'язбереження і дослідницьку діяльність). У контексті готовності до роботи у профільній школі принципово іншою бачиться система технологій навчання, що має бути зорієнтованою на побудову навчального процесу на концептуальній основі, навчання укрупненими дидактичними одиницями, організаційно-ділові імітаційні ігри, технологію КСН (колективного способу навчання), технологію повного засвоєння знань, комп'ютерні технології навчання, диференційоване навчання, ТРДЗ (технологію розв'язання дослідницьких задач), технологію проектного навчання тощо. Ступінь профілізації навчального процесу залежить від педагогічної, психологічної, поліпредметної, методичної, загальнокультурної готовності вчителя природничих дисциплін, від того, наскільки кваліфіковано створюються передумови для самореалізації особистості, розкриття їі природних задатків, прагнення до свободи, відповідальності, творчості.

Висновки. Отже, розроблено методами теоретичного, генетичного, функціонально-структурного моделювання 3 виокремленням комплексу цінностей, фахових знань і досвіду та визначенням сукупності основних компетенцій для конструювання наскрізної професійно-педагогічної програми, що має інтегрований характер, й експериментально перевірено організаційно-функціональну моделі поетапної професійної підготовки, особистісної готовності майбутнього вчителя природничих дисциплін до професійної діяльності у профільній школі. Пропонована модель має за мету формування профільно зорієнтованої компетентності особистості майбутнього вчителя природничих дисциплін, побудована за принципами сендвіч-технологій моделювання системи професійно-педагогічної підготовки студентів до роботи у профільній школі на основі виокремлення чотирьох функціональних площин (підсистем): зовнішньої або соціальної; загальної або площини реалізації професійно педагогічної підготовки; внутрішньої або структурно-змістової; локальної або прикладної. Модель відповідає концепції дослідження як компетентнісно-концентричній цілісності процесу поетапної професійної підготовки, відображає структуру, взаємозв’язки між етапами й системою технологій навчання. Це дає змогу наукового відтворення і більш глибокої деталізації інформації про об'єкт дослідження, забезпечення його змін, використання таких чинників формування майбутнього фахівця: спільного ринку освітніх послуг та виховного простору як педагогічно доцільно організованого середовища; інноваційної спрямованості методолого-теоретичних, науково-методичних i практикотехнологічних аспектів підготовки; моделювання процесу саморозвитку як цілісної особистісної системи на засадах самостійної начальної діяльності; встановлення зворотних інформаційних зв'язків між площинами як елементами системи підготовки; запровадження наскрізних діагностичних i експертних методів аналізу якості й результативності підготовки майбутніх учителів до професійної діяльності у профільній школі; організації 
співробітництва і співтворчості суб'єктів підготовки на основі кооперативних взаємозв'язків, утвердження цінності людської праці й думки; цілісного формування інноваційної спрямованості, рефлексивної поведінки, системного й ситуаційного мислення особистості впродовж тривалого періоду взаємодії та педагогічного супроводу в рамках підготовки. Модель відтворює реальну ринково-педагогічну дійсність професійної підготовки майбутнього вчителя природничих дисциплін, має прогностичний характер та забезпечує особистісний i соціальний результат - якість і конкурентноздатність майбутніх учителів профільної школи на ринку освітніх послуг.

\section{Література}

1. Професійно-педагогічна освіта: сучасні концептуальні моделі та тенденції розвитку: [монографія] / авт. кол. О.А. Дубасенюк, О. Є. Антонова, С. С. Вітвицька, Н. Г. Сидорчук, О. М. Спірін, Н. В. Якса та ін.; за заг. ред. проф. О. А. Дубасенюк: [2-е вид., доп. ]. - Житомир : Вид-во ЖДУ ім. І. Франка, 2008. - 380 с.

2. Сидорчук Н. Г. Організація самоосвітньої діяльності майбутніх учителів у процесі вивчення предметів педагогічного циклу : дис. ... канд. пед. наук : 13.00 .04 / Н. Г. Сидорчук. - К., 2002. -218 с.

3. Томашевський В. М. Моделювання систем / В. М. Томашевський. - К. : Видавнича група BHV, 2005. - 352c.

4. Шутюк С. В. Моделирование системы взаимоотношений крупных компаний с регионами : [научная монография] / С. В. Шутюк. - М. : ВИНИТИ РАН, 2006. -336 c.

Стаття надійшла до редакції 27.05.2012 p.

УДК 378.147:373.3

I. В. Онищенко, кандидат філол. наук, дочент, Криворізький педагогічний інститут ДВНЗ «Криворізький національний університет»

\section{ФОРМУВАННЯ ТВОРЧОЇ КОМПЕТЕНТНОСТІ МАЙБУТНЬОГО ВЧИТЕЛЯ ПОЧАТКОВИХ КЛАСІВ У ПРОЦЕСІ ПРОФЕСІЙНОЇ ПІДГОТОВКИ}

Онищенко І. В. Формування творчої компетентності майбутнього вчителя початкових класів у прочесі професійної підготовки.

У статті розглянуто проблему формування творчої компетентності майбутнього вчителя початкових класів, визначено сутність, структуру, умови та шляхи формування творчої компетентності майбутнього вчителя початкової школи у прочесі фахової підготовки.

Ключові слова: компетентність, творча компетентність, творча особистість, творчий учитель, творча активність.

Онищенко И. В. Формирование творческой компетентности будущего учителя начальных классов в прочессе профессиональной подготовки.

В статье рассматривается проблема формирования творческой компетентности будущего учителя начальных классов, определяется сущность, структура, условия и пути формирования творческой компетентности будущего учителя начальной школь в процессе профессиональной подготовки.

Ключевые слова: компетентность, творческая компетентность, творческая личность, творческий учитель, творческая активность. 